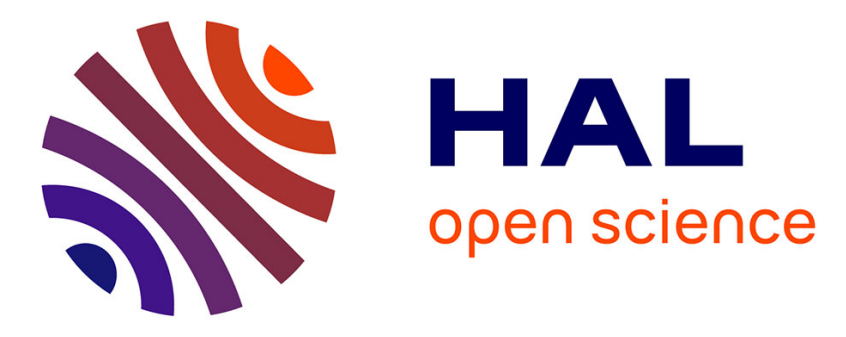

\title{
Capacités rythmiques des patients parkinsoniens avec freezing
}

Frédéric Puyjarinet, Christian Geny, Christine Azevedo Coste, Benoît Sijobert, Valentin Bégel, Claudia Verna, Valérie Cochen De Cock, Benoit Bardy, Simone Dalla Bella

\section{To cite this version:}

Frédéric Puyjarinet, Christian Geny, Christine Azevedo Coste, Benoît Sijobert, Valentin Bégel, et al.. Capacités rythmiques des patients parkinsoniens avec freezing. Neurophysiologie Clinique = Clinical Neurophysiology, 2017, 47 (5-6), pp.\#339. 10.1016/j.neucli.2017.10.008 • lirmm-01905215

\section{HAL Id: lirmm-01905215 https://hal-lirmm.ccsd.cnrs.fr/lirmm-01905215}

Submitted on 25 Oct 2018

HAL is a multi-disciplinary open access archive for the deposit and dissemination of scientific research documents, whether they are published or not. The documents may come from teaching and research institutions in France or abroad, or from public or private research centers.
L'archive ouverte pluridisciplinaire HAL, est destinée au dépôt et à la diffusion de documents scientifiques de niveau recherche, publiés ou non, émanant des établissements d'enseignement et de recherche français ou étrangers, des laboratoires publics ou privés. 
au traitement dopaminergique avant l'intervention suggérant la modulation de circuits neuronaux différents.

Mots clés Maladie de Parkinson; Initiation du pas ; Stimulation cérébrale profonde ; Noyau sous-thalamique

Déclaration de liens d'intérêts Les auteurs déclarent ne pas avoir de liens d'intérêts.

https://doi.org/10.1016/j.neucli.2017.10.006

\section{5 \\ Pisa syndrome in Parkinson's disease caused by biased spatial referentials? No}

Piscicelli Céline ${ }^{1,2, *}$, Castrioto Anna ${ }^{3,4}$, Debu Bettina ${ }^{4}$, Jaeger Marie ${ }^{1}$, Fraix Valérie ${ }^{3,4}$, Moro Elena ${ }^{3,4}$,

Perennou Dominic ${ }^{1,2,5}$, Krack Paul ${ }^{3,4,6}$

${ }^{1}$ Département de rééducation neurologique, $\mathrm{CHU}$ de Grenoble-Alpes, Grenoble, France

2 Laboratoire de psychologie et neurocognition CNRS UMR 5105, université Grenoble-Alpes, Grenoble, France

${ }^{3}$ Département de psychiatrie et neurologie, unité des troubles du mouvement, $\mathrm{CHU}$ de Grenoble-Alpes, Grenoble, France

${ }^{4}$ Institut de neuroscience de Grenoble, Inserm-UJF-CEA U836,

Grenoble, France

${ }^{5}$ Université Joseph-Fourier Grenoble-Alpes, Grenoble, France

${ }^{6}$ Département des neurosciences cliniques, hôpitaux

universitaires de Genève, Switzerland

* Corresponding author. Département de rééducation

neurologique, CHU de Grenoble-Alpes, Grenoble, France.

E-mail address: CPiscicelli@chu-grenoble.fr (P. Céline)

Introduction It has been recently hypothesized that Pisa syndrome (PS), the most dramatic form of lateral trunk tilt occurring in persons with $\mathrm{PD}$, might be caused by a bias in one of the key spatial referential. Despite many recent papers, this issue remains to be solved. This study is the first to comprehensively investigate the representation of the vertical ( 2 modalities: visual [VV] and postural $[\mathrm{PV}])$, together with the representation of the long body axis (LBA) in a group of PD patients with PS.

Methods The study consisted in a double-blind controlled trial manipulating conditions of deep brain stimulation (DBS) in 18 PD participants (63.4 [5] years, 11 females, disease duration 18.5 [4.7] years) treated with bilateral DBS of the subthalamic nuclei (STN) (11.8 [2.9] years postdiagnosis) and presenting with a PS. VV, PV and LBA were tested off medication under four condition of STN stimulation (bilateral on, bilateral off, unilateral on/off, unilateral off/on). Motor state (UPDRS), scoliosis and lateral trunk tilt were also precisely assessed. Twenty healthy age- and gender-matched participants were also included (61.4 [6.4] years, 12 females, $P=0.36$ and $P=0.94$ ).

Results The median lateral trunk tilt was $7.6^{\circ}(5.5)$ when patients were instructed to stand as upright as possible. Scoliosis prevalence was high $(71 \%)$ with a mean Cobb angle $18.8^{\circ}(7.6)$. No link was found between the side of the PS and the asymmetry of denervation at the onset of the disease $(10 / 18$ tilted to the side of the most denervated striatum) or asymmetry of current symptoms (11/18 tilted toward the most affected hemibody). Spatial referential were more frequently biased in PS than in controls $(P<0.05)$ : VV 7/18; PV 4/18; LBA. Transmodal vertical biases $(V V+P V)$ were rare: $2 / 18$. A possible causal relationship between any of these biases and PS was found in only 3 participants. No statistical rule was found between any of biased referential (side or magnitude) and the trunk tilt (side or magnitude). No spatial referential was modulated by DBS.

Discussion-conclusion If VV, PV and LBA are frequently biased in $\mathrm{PD}$ persons with $\mathrm{PS}$, this is not the origin of their lateral trunk tilt. Keywords Parkinson's disease; Pisa syndrome; Spatial cognition; Neuromodulation
Disclosure of interest The authors declare that they have no competing interest.

https://doi.org/10.1016/j.neucli.2017.10.007

06

\section{Capacités rythmiques des patients parkinsoniens avec freezing}

Frédéric Puyjarinet ${ }^{1}$, Christian Geny ${ }^{1,2}$, Christine Azevedo ${ }^{3}$, Benoît Sjobert $^{3}$, Valentin Bégel ${ }^{1,4}$, Claudia Verna ${ }^{2}$, Valérie Cochen de Cock $^{1,5}$, Benoît Bardy ${ }^{1,6}$,

Simone Dalla Bella ${ }^{1, *, 6,7}$

${ }_{1}^{1}$ Laboratoire Euromov, université de Montpellier, 900, avenue du Pic-Saint-Loup, 34090 Montpellier, France

2 Service de neurologie, CHRU de Montpellier-Gui-de-Chauliac, Montpellier, France

${ }^{3}$ INRIA, LIRMM, université de Montpellier, Montpellier, France

${ }^{4}$ SAS NaturalPad, Montpellier, France

${ }^{5}$ Clinique Beau-Soleil, Montpellier, France

${ }^{6}$ Institut universitaire de France (IUF), Paris, France

7 International Laboratory for Brain, Music and Sound Research (BRAMS), Montreal, Canada

* Auteur correspondant.

Adresse e-mail : simone.dalla-bella@umontpellier.fr (S.D. Bella)

Contexte Les patients souffrant de la maladie de Parkinson (MP) présentent des déficits dans la sphère du rythme, largement documentés. Ils ont des difficultés dans la discrimination perceptuelle de rythmes auditifs et dans la synchronisation du mouvement avec des stimuli rythmiques (métronomes ou musique). Cependant, nous ne savons pas jusqu'ici si ces déficits peuvent contribuer à distinguer différents profils de troubles du mouvement dans la MP, tels que la présence ou l'absence d'enrayage cinétique (freezing).

Méthodes Deux groupes de patients avec MP (14 avec enrayage cinétique et 18 sans), comparables en termes d'âge et de durée de la maladie, ont passé une batterie de tests rythmiques : la battery for the assessment of auditory sensorimotor and timing abilities, BAASTA. Celle-ci incluait des tâches de perception de rythmes (e.g., détecter une irrégularité rythmique) et des tâches motrices (e.g., frapper avec la main au rythme d'une musique). Les patients avec MP étaient comparés à un groupe de 39 participants témoins.

Résultats Les patients avec enrayage cinétique étaient plus variables et moins précis que les autres patients et les participants témoins, sur des tâches de production de séquences rythmiques et de synchronisation à un rythme. Des déficits accrus chez ces patients ont aussi été observés dans la détection d'une irrégularité (tâche perceptuelle) avec des rythmes simples.

Conclusions Des déficits particulièrement sévères du traitement du rythme caractérisent les patients avec enrayage cinétique. Ce symptôme, apparaissant à un stade avancé de la maladie, pourrait être lié à la dégradation des circuits neuronaux sous-jacents au traitement rythmique.

Mots clés Syndrome parkinsonien ; Freezing

Déclaration de liens d'intérêts Les auteurs déclarent ne pas avoir de liens d'intérêts.

https://doi.org/10.1016/j.neucli.2017.10.008

07

\section{Marche en double tâche chez le patient traumatisé crânien : caractérisation des troubles et retentissement}

Laurine Abadie ${ }^{1,2,3,4,5}$, Odile Kozlowski ${ }^{1,2,3,4,5}$, Khaldoun Youssef $1,2,3,4,5$, Caroline Rogeau ${ }^{1,2,3,4,5}$, Walter Daveluy ${ }^{1,2,3,4,5}$, Anne Benoit ${ }^{1,2,3,4,5}$, Etienne Allart ${ }^{1, *}$ 